\title{
Species-Specific Features of Neuron-Glial Populations in the Brain of Tailless Amphibians
}

\author{
Liubov' N. Afanaskina* and Nadezhda N. Medvedeva \\ V.F. Voyno-Yasenetsky Krasnoyarsk State Medical University \\ 1 Partizan Zheleznyak Str., Krasnoyarsk, 660022, Russia
}

Received 07.10.2018, received in revised form 16.01.2019, accepted 29.03.2019

The midbrain roof and cerebellum cortex are the main integrative centers in amphibians. They serve to analyze and process nerve impulses, form the organism's response, regulate and coordinate movements, connect amphibians with their environments. The present study addresses the relationship between the species of the tailless amphibians inhabiting the southern part of the Krasnoyarsk region (Bufo bufo Linnaeus, Rana arvalis Nilsson, Pelophylax ridibundus Pallas, and Rana amurensis Boulenger) and the morphological parameters of the populations of neurons and glia in layer VI of the midbrain roof and layers of the cerebellum cortex. The species-specific structure of amphibians' brain regions has been found to be evident not only at the organ level (size and shape), but also at the level of the organization of neuron and glial cell populations. Distinctive species-specific differences can be found in the parameters of cell area (the area of the body, the area of the nucleus and the area of the cytoplasm) and the distribution density of neurons and gliocytes. The development of specific morphological features at the cellular level of the arrangement of the midbrain and cerebellum layers in different species of tailless amphibians is associated with long-term phylogenetic transformations of their nervous system and adaptation of amphibians to the terrestrial-aquatic habitat.

Keywords: amphibians, the midbrain, neurons, cell populations, morphometry.

Citation: Afanaskina L.N., Medvedeva N.N. Species-specific features of neuron-glial populations in the brain of tailless amphibians. J. Sib. Fed. Univ. Biol., 2019, 12(4), 445-459. DOI: 10.17516/1997-1389-0311

(C) Siberian Federal University. All rights reserved

This work is licensed under a Creative Commons Attribution-NonCommercial 4.0 International License (CC BY-NC 4.0),

* Corresponding author E-mail address: afanln@mail.ru

ORCID: 0000-0002-7757-6628 (Medvedeva N.) 


\title{
Видовые особенности нейрон-глиальных популяций головного мозга бесхвостых амфибий
}

\author{
Л.Н. Афанаскина, Н.Н. Медведева \\ Красноярский государственный медицинский университет \\ им. проф. В.Ф. Войно-Ясенеикого \\ Россия, 660022, Красноярск, ул. Партизана Железняка, 1
}

Крыша среднего мозга и кора мозжечка являются у амфибий ведущими интегративными центрами. Они обеспечивают анализ и обработку нервных импульсов, формирование ответной реакции организма, регуляцию и координацию движений, связь земноводных с условиями среды. В работе рассмотрена связь между видовой принадлежностью бесхвостых земноводных южной части Красноярского края (Bufo bufo Linnaeus, Rana arvalis Nilsson, Pelophylax ridibundus Pallas, Rana amurensis Boulenger) и морфологическими параметрами популящий нейронов и глии VI слоя крыши среднего мозга и слоев коры мозжечка. Установлено, что видовые особенности строения отделов головного мозга амфибий проявляются не только на органном уровне (размеры и форма), но и на уровне организации клеточных популяций нейронов и глии. Отличительные видовые особенности отмечены в параметрах площади клеток (площадь тела - Sm, площадь ядра - Sя и площуадь ичитоплазмы - Su) и плотности распределения нейронов и глиочитов. Появление у разных видов бесхвостых земноводных специфическихморфологическихособенностейнаклеточномуровне организации слоевсреднего мозга и мозжечка, вероятно, связано с длительными филогенетическими преобразованиями их нервной системы и адаптацией амфибий к наземно-водной среде обитания.

Ключевые слова: земноводные, средний мозг, нейроны, клеточные популяции, морфометрия.

Цитирование: Афанаскина, Л.Н. Видовые особенности нейрон-глиальных популяций головного мозга бесхвостых амфибий / Л.Н. Афанаскина, Н.Н. Медведева // Журн. Сиб. федер. ун-т. Биология, 2019. 12(4). С. 445-459. DOI: $10.17516 / 1997-1389-0311$

\section{Введение}

Амфибии как переходная форма живых организмов от водных к наземным позвоночным животным занимают незначительную экологическую нишу. Они сочетают признаки предковых форм и характеризуются появлением новых прогрессивных черт организации на уровне всех систем, в том числе и нервной (Орлянская, 2004). Нервная система как одна из ведущих регуляторных систем обуславливает взаимосвязь организма с окружающей средой и его адекватную ответную реакцию на воздействие различных факторов (Каниева, 2005).

В современных сравнительнонейрогистологических исследованиях земноводные используются достаточно редко. Имеющиеся литературные данные по цитоархитектонике и протеиноархитектонике структур головного мозга представителей разного уровня организации класса амфибии в норме единичны и касаются отдельных представителей (Антонова, 1969; Лешко, 1968; Карамян, 1970; Фанарджян, 1995, 
2000). На сегодняшний день практически отсутствуют комплексные количественные морфологические исследования, позволяющие оценить гетерогенность популяций нейронов среднего мозга и мозжечка в ходе их преобразований в филогенезе позвоночных. При этом изучение преобразований головного мозга у представителей класса земноводных имеет ключевое значение для понимания процессов формирования центральной нервной системы наземных позвоночных, что обуславливает актуальность исследования.

Исследование типичных (модельных) представителей разных позвоночных животных для характеристики отдельных систематических групп не всегда в полной мере отражает все многообразие их признаков и уровня организации. Данными палеонтологии, сравнительной анатомии и нейроморфологии подтверждена значительная неравномерность хода эволюции, ее мозаичность при формировании и преобразовании разных структур и признаков ЦНС, неравномерное, иногда параллельное, независимое развитие даже в близкородственных группах. Поэтому при изучении эволюции нервной системы позвоночных животных перспективным является исследование возможно большего количества представителей современных видов (Андреева, Обухов, 1999).

Ранние исследования нервной системы земноводных посвящены изучению структурной организации их головного мозга, перестройкам его отделов и слоев в ходе филогенеза позвоночных, формированию коры, дифференцировке клеточных структур и внутримозжечковых ядер, совершенствованию выполняемых функций (Сепп, 1949; Comparative neurology of the optic tectum, 1984; Ulinski, 1990; Butler, Hodos, 2005; Striedter, 2005).
Исследования последних лет в области нейроморфологии центральной нервной системы земноводных связаны с изучением отличительных особенностей организации, нейрогенеза и пролиферативных зон взрослых амфибий (Обухов, Пущина, 2013; Обухов и др., 2015; Пущина и др., 2016; Chetverukhin, Polenov, 1993; Font et al., 2001). Практически единичны морфологические исследования ведущих отделов головного мозга (коры мозжечка, крыши среднего мозга) бесхвостых земноводных (Орлянская и др., 2006, 2008; Самосудова и др., 2007, 2011). Отдельное внимание уделено характеристике строения коры мозжечка и крыши среднего мозга некоторых видов бесхвостых амфибий с точки зрения их двигательной активности и эволюционных преобразований позвоночных животных (Opлянская, Самсонова, 2006; Крупкина, Орлянская, 2008).

Целью нашего исследования стало выявление особенностей морфологических характеристик клеточных популяций нейронов и глиоцитов головного мозга бесхвостых амфибий, обитающих на территории южной части Красноярского края, в зависимости от их видовой принадлежности.

\section{Материалы и методы}

Красноярский край занимает значительную территорию с различными климатическими зонами, но видовой состав батрахофауны очень бедный. Он представлен четырьмя видами бесхвостых амфибий, относящихся к семействам: Bufonidae Жабы (Bufo bufo Linnaeus - серая (обыкновенная) жаба) и Ranidae - Лягушки (Rana arvalis Nilsson - остромордая лягушка, Pelophylax ridibundus Pallas - озерная лягушка, Rana amurensis Boulenger - сибирская лягушка) (Чупров, 2013; Баранов, Городилова, 2015). Исследования проведены 
на амфибиях, отловленных в мае-июне 2008-2010 гг. из следующих биотопов Красноярского края: B. bufo - пойма р. Канзыба, Курагинский район ( $\mathrm{n}=7, \mathrm{~m}=48,6 \pm 0,9$ г); R. arvalis - пруд Егоровка, Абанский район (n $=10, \mathrm{~m}=18,8 \pm 1,9$ г); P. ridibundus - пойма р. Берешь, Шарыповский район (n = 7, $\mathrm{m}=38,4 \pm 4,2$ г); R. amurensis - о3. Кунгул, Иланский район $(\mathrm{n}=8, \mathrm{~m}=21,6 \pm 0,9$ г). Всего отловлено 32 амфибии.

Забор материала для исследования проводили в соответствии с соблюдением требований приказа Министерства здравоохранения и социального развития РФ от 23.08.2010 № 708н г. Москва «Об утверждении правил лабораторной практики». После извлечения из черепной коробки головной мозг был фиксирован согласно стандартной гистологической методике, затем на санном микротоме «Slide 2002» осуществляли изготовление серийных гистологических срезов толщиной 5-7 мкм (Орлянская и др., 2006). Срезы головного мозга окрашивали тионином по Нисслю в модификации И.В. Викторова на выявление рибонуклеопротеидных комплексов (Викторов, 1969). Исследуемые структуры: VI слой крыши среднего мозга и слои коры мозжечка (молекулярный слой, слой грушевидных нейронов и зернистый слой) - высшие интегрирующие центры, обеспечивающие регуляцию и координацию движений амфибий. Крыша среднего мозга земноводных содержит поверхностную и центральную зоны, образованные приходящими афферентными волокнами и отростками клеток, и перивентрикулярную зону, сформированную телами клеток. Бесхвостые земноводные имеют развитую зрительную систему, в крыше их среднего мозга описано 9 слоев (Андреева, Обухов, 1999). Эфферентным слоем крыши среднего мозга амфибий является VI слой, лежащий в перивентрикулярной зоне, нейроны которого аналогичны IV слою мозга этого отдела у костных рыб (Орлянская, Самсонова, 2006).

У взрослых животных кора мозжечка в виде гладкого валика представлена тремя морфологически различающимися слоями: молекулярным, обращенным к крыше мозга, содержащим звездчатые нейроны и практически лишенным миелинизированных волокон; слоем грушевидных нейронов с крупными телами клеток Пуркинье; зернистым слоем с более светлым подслоем от входящего в него афферентного пучка, содержащим множество зернистых клеток (Андреева, Обухов, 1999).

Для проведения морфометрии срезы головного мозга фотографировали на микроскопе Olympus BX45 с насадкой для фото-, видеодокументации Olympus DP25 и пакетом компьютерного программного обеспечения Cell^D (объектив ×40). Для морфогистологического анализа использовали программы «NIS-Elements D» и «JMicroVision 1.2.7» (Жуков, Медведева, 2015). Изучены характеристики клеток: площадь тела - ST, площадь ядра - Sя, площадь цитоплазмы - Sц и их производное-ЯЦК (ядерно-цитоплазматический коэффициент, отношение Sя / Sц). В изучаемых слоях головного мозга амфибий проанализированы плотность нервных и глиальных клеток на единицу фиксированной площади $\left(1 \mathrm{MM}^{2}\right)$. Глио-нейрональный индекс (ГНИ) рассчитывали как соотношение числа глиальных клеток к числу нервных клеток (Nгл / Nнк). Полученные данные обрабатывали, применяя непараметрический критерий Ньюмана-Кейлса в программе EXCEL STAT (Гланц, 1999). Статистически значимыми принимали значения при $\mathrm{p}<0,05$. Статистические данные представлены в виде Ме [25; 75], где 25 - первый квартиль, 75 - третий квартиль. 


\section{Результаты и обсуждение}

Крыша среднего мозга - высший оптический центр. Уровень его развития и дифференцировка у амфибий связаны с экологофункциональным значением органа зрения (Андреева, Обухов, 1999). В среднем мозге бесхвостых земноводных выделяют примитивное четверохолмие с большим анатомическим развитием у семейства Bufonidae. Прогрессивная морфофункциональная организация мозжечка обусловливает более совершенную моторику конечностей при перемещении амфибий на суше (ползание у представителей семейства Bufonidae). Также лучше развит средний мозг как высший центр их оптической системы.

Нервная ткань гетерогенна, что выражается в присутствии различных по морфологическим и функциональным свойствам крупных клеточных популяций нейронов и нейроглии, каждая из которых содержит клетки, различающиеся по форме и функциям. Среди изученных видов бесхвостых амфибий самые крупноклеточные популяции нейронов VI слоя крыши среднего мозга и слоев коры мозжечка встречаются у P. ridibundus (табл. 1). Площадь тела их клеток превышает аналогичные параметры нейронов других видов на $30-40 \%$. При этом наблюдается относительно высокая гетерогенность клеточных популяций в слоях головного мозга у данного вида, что свидетельствует о подключении адаптивных механизмов на клеточном уровне у амфибий, осваивающих новые территории обитания.

Наименьшая площадь тел нейронов во всех изученных слоях головного мозга наблюдается у $R$. arvalis. Их клеточные популяции имеют наименьшую гетерогенность, что свидетельствует об оптимальном функционировании без подключения компенсаторных механизмов. Можно предположить, что в среде обитания остромордой лягушки, фонового вида на территории южной части Красноярского края, отсутствуют жесткие факторы естественного отбора и повышенное антропогенное влияние. Параметры Sт клеток и диапазон разброса вариант данного показателя у B. bufo и R. amurensis имеют промежуточные значения среди изучаемых видов амфибий, что отражает их видоспецифичность (табл. 1).

У изученных видов бесхвостых амфибий нейроны VI слоя крыши среднего мозга, звездчатые нейроны молекулярного слоя и зернистые клетки зернистого слоя коры мозжечка имеют более высокие значения показателей Sя над Sц, что отражают величины структурного ЯЦК (значения 1,0 - 1,7). Эфферентные клетки Пуркинье слоя грушевидных нейронов коры мозжечка имеют значительный объем цитоплазмы, превышающий площадь ядра до $70 \%$. Значения структурного ЯЦК этих нейронов составили $0,8-0,9$ (табл. 1).

Плотность нейронов изучаемых слоев мозга амфибий имела видоспецифические особенности. Наибольшие показатели плотности нервных клеток VI слоя крыши среднего мозга, звездчатых нейронов молекулярного слоя и зернистых клеток зернистого слоя коры мозжечка характерны для B. bufo, а наименьшие - для R. arvalis (табл. 1, рис. 1, 2). В слое грушевидных нейронов коры мозжечка плотность клеток Пуркинье была максимальна у $R$. amurensis, а минимальна - у B. bufo.

Важной отличительной морфологической особенностью нервной ткани является существенная гетерогенность ее клеточного состава. Нейроны, выполняющие специфические функции в центральной нервной системе, составляют небольшую часть, а глиальные клетки значительно преобладают над нервными и занимают весь объем между сосудами и нейронами (Васильев, Берестов, 2011). 
Таблица 1. Морфологические показатели нейрон-глиальных популяций VI слоя крыши среднего мозга и коры мозжечка бесхвостых амфибий

Table 1. Morphological parameters of neuron-glial populations of layer VI in the midbrain roof and the cerebellum cortex of tailless amphibians

\begin{tabular}{|c|c|c|c|c|}
\hline Параметр & $\begin{array}{l}\text { VI слой крыши } \\
\text { среднего мозга }\end{array}$ & $\begin{array}{c}\text { Молекулярный } \\
\text { слой коры } \\
\text { мозжечка }\end{array}$ & \begin{tabular}{|c|} 
Слой грушевидных \\
нейронов коры \\
мозжечка
\end{tabular} & $\begin{array}{l}\text { Зернистый слой } \\
\text { коры мозжечка }\end{array}$ \\
\hline 1 & 2 & 3 & 4 & 5 \\
\hline \multicolumn{5}{|c|}{$1-B . b u f o$} \\
\hline $\mathrm{ST}$, мкм $^{2}$ & $20,7[17,4 ; 23,6]^{2-4}$ & $10,4[9,3 ; 11,6]^{2,3}$ & $29,6[25,1 ; 33,3]^{3}$ & $11,1[8,7 ; 12,9]^{2,3}$ \\
\hline Sя, мкм ${ }^{2}$ & $13,1[10,7 ; 15,4]^{2-4}$ & $5,5[4,8 ; 6,3]^{2,3}$ & $14,9[11,3 ; 18,1]^{2,3}$ & $5,7[4,4 ; 7,1]^{2,3}$ \\
\hline Sц, мкм ${ }^{2}$ & $7,4[6,5 ; 8,2]^{2-4}$ & $4,9[4,3 ; 5,6]^{2,3}$ & $14,2[11,9 ; 16,9]^{3,4}$ & $5,1[4,2 ; 6,0]^{2-4}$ \\
\hline сЯЦК & $1,7[1,6 ; 2,0]^{2-4}$ & $1,1[1,0 ; 1,3]^{2,3}$ & $1,0[0,7 ; 1,3]^{2,3,4}$ & $1,1[0,9 ; 1,3]^{2,4}$ \\
\hline$\rho$ нейронов, кл/мм² & $\begin{array}{l}8617,4[7943,2 ; \\
9421,0]^{2-4}\end{array}$ & $\begin{array}{l}1249,1[831,3 \\
1477,8]^{2-4}\end{array}$ & $\begin{array}{l}712,5[554,2 ; 923,6] \\
2,4\end{array}$ & $\begin{array}{l}43890,8[37494,0 ; \\
50540,9]^{2-4}\end{array}$ \\
\hline $\begin{array}{l}\rho \text { глии своб., } \\
\text { кл/мм }{ }^{2}\end{array}$ & $\begin{array}{l}2770,9[2216,7 ; \\
3325,1]^{2-4}\end{array}$ & $\begin{array}{l}779,5[554,2 ; 923,6] \\
2-4\end{array}$ & $\begin{array}{l}639,9[484,9 ; 923,6] \\
2-4\end{array}$ & - \\
\hline$\rho$ глии сат., кл/мм² & $\begin{array}{l}1939,6[1662,5 ; \\
2216,7]^{2-4}\end{array}$ & $\begin{array}{l}554,2[403,0 ; 692,7] \\
2-4\end{array}$ & $\begin{array}{l}277,1[184,7 ; 369,5] \\
3,4\end{array}$ & - \\
\hline ГНИ своб. & $0,3[0,3 ; 0,3]^{2-4}$ & $0,6[0,4 ; 1,0]^{2-4}$ & $1,0[0,7 ; 1,4]^{2-4}$ & - \\
\hline ГНИ сат. & $0,2[0,2 ; 0,3]^{2,3}$ & $0,4[0,3 ; 0,8]^{2-4}$ & $0,4[0,3 ; 0,5]^{2-4}$ & - \\
\hline \multicolumn{5}{|c|}{$2-R$. arvalis } \\
\hline $\mathrm{ST}$, мкм $^{2}$ & $14,8[12,2 ; 17,2]^{1,3,4}$ & $8,0[6,8 ; 9,0]^{1,3,4}$ & $28,2[21,5 ; 33,9]^{3,4}$ & $9,6[8,3 ; 11,6]^{1,3}$ \\
\hline Sя, мкм² & $9,2[7,2 ; 10,8]^{1,4}$ & $4,8[3,9 ; 5,6]^{1,3,4}$ & $11,1[8,3 ; 14,7]^{1,3,4}$ & $6,0[4,9 ; 7,5]^{1,3}$ \\
\hline Сц, мкм ${ }^{2}$ & $5,8[5,1 ; 6,5]^{1,3,4}$ & $3,2[2,8 ; 3,5]^{1,3,4}$ & $14,7[11,1 ; 19,7]$ & $3,6[3,2 ; 4,0]^{1,3,4}$ \\
\hline сЯЦК & $1,6[1,4 ; 1,7]^{1,3,4}$ & $1,5[1,3 ; 1,7]^{1,3,4}$ & $0,8[0,6 ; 1,0]^{1}$ & $1,7[1,5 ; 2,0]^{1,3,4}$ \\
\hline$\rho$ нейронов, кл/мм² & $\begin{array}{l}5911,2[5541,8 \\
6650,1]^{1,3,4}\end{array}$ & $\begin{array}{l}339,2[307,7 ; 399,4] \\
1,4\end{array}$ & $\begin{array}{l}1154,5[831,3 \\
1662,5]^{1,3}\end{array}$ & $\begin{array}{l}28373,8[23940,4 ; \\
33102,8]^{1,4}\end{array}$ \\
\hline $\begin{array}{l}\rho \text { глии своб., } \\
\text { кл/мм }{ }^{2}\end{array}$ & $\begin{array}{l}3325,1[2770,9 \\
4156,3]^{1,3,4}\end{array}$ & $\begin{array}{l}184,7[138,5 ; 237,5] \\
1,3,4\end{array}$ & $\begin{array}{l}277,1[138,5 ; 369,5] \\
1,3,4\end{array}$ & - \\
\hline$\rho$ глии сат., кл/мм² & $\begin{array}{l}2216,7[1847,3 ; \\
2493,8]^{1}\end{array}$ & $\begin{array}{l}110,8[0,0 ; 138,5] \\
1,3,4\end{array}$ & $\begin{array}{l}221,7[138,5 ; 369,5] \\
3,4\end{array}$ & - \\
\hline ГНИ своб. & $0,6[0,5 ; 0,7]^{1,3,4}$ & $0,6[0,4 ; 0,7]^{1,3,4}$ & $0,2[0,1 ; 0,3]^{1,3,4}$ & - \\
\hline ГНИ сат. & $0,4[0,3 ; 0,4]^{1,3,4}$ & $0,3[0,0 ; 0,4]^{1,4}$ & $0,2[0,1 ; 0,3]^{1,3,4}$ & - \\
\hline \multicolumn{5}{|c|}{$3-P$. ridibundus } \\
\hline $\mathrm{ST}$, мкм $^{2}$ & $21,8[18,8 ; 25,3]^{1,2,4}$ & $13,7[11,3 ; 16,6]^{1,2,4}$ & $41,3[36,8 ; 45,3]^{1,2,4}$ & $15,9[13,8 ; 18,5]^{1,2,4}$ \\
\hline Sя, мкм ${ }^{2}$ & $13,0[11,3 ; 15,2]^{1,4}$ & $6,6[5,0 ; 8,7]^{1,2,4}$ & $17,6[13,1 ; 21,5]^{1,2,4}$ & $8,2[6,8 ; 9,8]^{1,2,4}$ \\
\hline Sц, мкм ${ }^{2}$ & $8,8[7,8 ; 10,1]^{1,2,4}$ & $6,8[6,0 ; 7,9]^{1,2,4}$ & $22,7[19,6 ; 27,6]^{1,4}$ & $7,6[6,7 ; 8,7]^{1,2,4}$ \\
\hline сЯЦК & $1,5[1,3 ; 1,7]^{1,2,4}$ & $1,0[0,8 ; 1,1]^{1,2,4}$ & $0,8[0,6 ; 1,0]^{1,4}$ & $1,0[0,9 ; 1,2]^{2,4}$ \\
\hline$\rho$ нейронов, кл/мм² & $\begin{array}{l}\text { 6580,8 [5911,2; } \\
7758,5]^{1,2,4} \\
\end{array}$ & $\begin{array}{l}609,6[484,9 ; 785,1] \\
1,4\end{array}$ & $725,7[475,0 ; 1108,4]$ & $\begin{array}{l}29246,7[24910,2 ; \\
32169,9]^{1,4}\end{array}$ \\
\hline $\begin{array}{l}\rho \text { глии своб., } \\
\text { кл/мм }{ }^{2}\end{array}$ & $\begin{array}{l}3048,0[2632,3 ; \\
3602,1]^{1,2,4}\end{array}$ & $\begin{array}{l}643,0[453,4 ; 862,1] \\
1,2,4\end{array}$ & $\begin{array}{l}735,4[401,4 ; 979,7] \\
1,2,4\end{array}$ & - \\
\hline$\rho$ глии сат., кл/мм² & $\begin{array}{l}2147,4[1773,4 \\
2493,8]^{1,4}\end{array}$ & $\begin{array}{l}184,7[138,0 ; 283,4] \\
1,2,4\end{array}$ & $\begin{array}{l}461,8[316,7 ; 554,2] \\
1,2,4\end{array}$ & - \\
\hline ГНИ своб. & $0,5[0,4 ; 0,5]^{1,2,4}$ & $1,1[0,6 ; 1,5]^{1,2,4}$ & $0,9[0,7 ; 1,2]^{1,2,4}$ & - \\
\hline ГНИ сат. & $0,3[0,3 ; 0,4]^{1,2,4}$ & $0,3[0,2 ; 0,5]^{1,4}$ & $0,6[0,4 ; 1,0]^{1,2,4}$ & - \\
\hline
\end{tabular}


Продолжение таблица 1

Continuation of Table 1

\begin{tabular}{|c|c|c|c|c|}
\hline 1 & 2 & 3 & 4 & 5 \\
\hline \multicolumn{5}{|c|}{$4-R$. amurensis } \\
\hline $\mathrm{ST}$, мкм $^{2}$ & $19,2[16,3 ; 22,0]^{1-3}$ & $11,0[9,7 ; 12,9]^{2,3}$ & $30,1[27,3 ; 35,3]^{2,3}$ & $10,2[9,0 ; 11,6]^{3}$ \\
\hline Sя, мкм ${ }^{2}$ & $11,1[9,2 ; 12,9]^{1-3}$ & $5,8[5,1 ; 6,9]^{2,3}$ & $15,2[12,9 ; 17,9]^{2,3}$ & $5,7[4,9 ; 6,6]^{3}$ \\
\hline $\mathrm{Sц}_{ц}$ мкм $^{2}$ & $7,9[6,8 ; 9,3]^{1-3}$ & $5,0[4,5 ; 5,7]^{2,3}$ & $15,4[13,6 ; 18,0]^{1,3}$ & $4,7[4,0 ; 5,3]^{1-3}$ \\
\hline сЯЦК & $1,4[1,2 ; 1,6]^{1-3}$ & $1,2[1,0 ; 1,3]^{2,3}$ & $0,9[0,8 ; 1,2]^{1,3}$ & $1,2[1,1 ; 1,4]^{1-3}$ \\
\hline$\rho$ нейронов, кл/мм ${ }^{2}$ & $\begin{array}{l}7619,9[6650,1 ; \\
8589,7]^{1-3}\end{array}$ & $\begin{array}{l}\text { 692,7 [665,0;831,3] } \\
1-3\end{array}$ & $\begin{array}{l}2826,3[2549,2 ; \\
3114,2]^{1}\end{array}$ & $\begin{array}{l}38127,3[34358,9 ; \\
39235,7]^{1-3}\end{array}$ \\
\hline $\begin{array}{l}\rho \text { глии своб., } \\
\text { кл/мм }{ }^{2}\end{array}$ & $\begin{array}{l}2355,2[1662,5 ; \\
2770,9]^{1-3}\end{array}$ & $\begin{array}{l}886,7[738,9 ; 1108,4] \\
1-3\end{array}$ & $\begin{array}{l}1154,5 \\
{[886,7 ; 1662,5]^{1-3}}\end{array}$ & - \\
\hline$\rho$ глии сат., кл/мм² & $\begin{array}{l}1662,5[1330,0 ; \\
1939,6]^{1,3}\end{array}$ & $\underset{1-3}{443,3[332,5 ; 554,2]}$ & $\begin{array}{l}775,8[649,5 ; 1108,4] \\
1-3\end{array}$ & - \\
\hline ГНИ своб. & $0,3[0,3 ; 0,4]^{1-3}$ & $1,2[1,0 ; 1,6]^{1-3}$ & $0,4[0,3 ; 0,6]^{1-3}$ & - \\
\hline ГНИ сат. & $0,2[0,2 ; 0,3]^{2,3}$ & $0,6[0,4 ; 0,8]^{1-3}$ & $0,3[0,2 ; 0,3]^{1-3}$ & - \\
\hline
\end{tabular}

Примечание: Sт - площадь профильного поля тела нервной клетки; Sц - цитоплазмы; Sя - ядра; сяЦК - структурный ядерно-цитоплазматический коэффициент; $\rho$ - плотность; своб. - свободная глия; сат. - сателлитная глия; ГНИ - глионейрональный индекс; Надстрочные индексы, обозначенные цифрами от 1 до 4, показывают наличие статистически значимых различий (критерий Ньюмана-Кейлса, $\mathrm{p}<0,05$ ) между значениями соответствующего параметра у данного вида и у вида(ов), на который(ые) указывает индекс.

Глия играет важную полифункциональную роль в деятельности нервной системы и обеспечении ее нормального функционирования (Васильев, Берестов, 2011; Дробленков и др., 2013; Устинова и др., 2015). В VI слое крыши среднего мозга амфибий наибольшие показатели плотности свободных и сателлитных глиоцитов имеет $R$. arvalis, а наименьшие $-R$. amurensis. В молекулярном слое и слое грушевидных нейронов коры мозжечка наивысшая плотность свободных глиоцитов наблюдается у $R$. amurensis, а сателлитных глиоцитов - у B. bufo и R. amurensis по слоям соответственно. Наименьшими показателями плотности глиоцитов в слоях грушевидных нейронов и молекулярном среди изученных видов земноводных располагает R. arvalis.

Высокая гетерогенность морфометрических признаков в нейронных популяциях клеток Пуркинье слоя грушевидных нейронов и VI слоя крыши среднего мозга (клеток, генери- рующих ответную реакцию со стороны ЦНС и выносящих информацию за пределы нервной системы) и зернистых клеток зернистого слоя коры мозжечка отражает специфические особенности данных слоев, указывает на широкие пластические и резервные возможности этих структур мозга в формировании приспособлений на популяционно-клеточном уровне и имеет важное адаптивное значение для жизнедеятельности земноводных.

Виды, входящие в семейство жабы (Bufonidae), имеют анатомические и морфофизиологические отличия, они менее связаны с водной средой, чем представители семейства лягушки (Ranidae) (Дунаев, Орлова, 2012). Данные семейства являются парафилетическими группами и имеют генетические различия (Frost et al., 2006; Pyron, Wiens, 2011). Особенности головного мозга разных семейств бесхвостых амфибий связаны с размером, уровнем развития и дифференцировки его отделов. Описание морфофункциональ- 

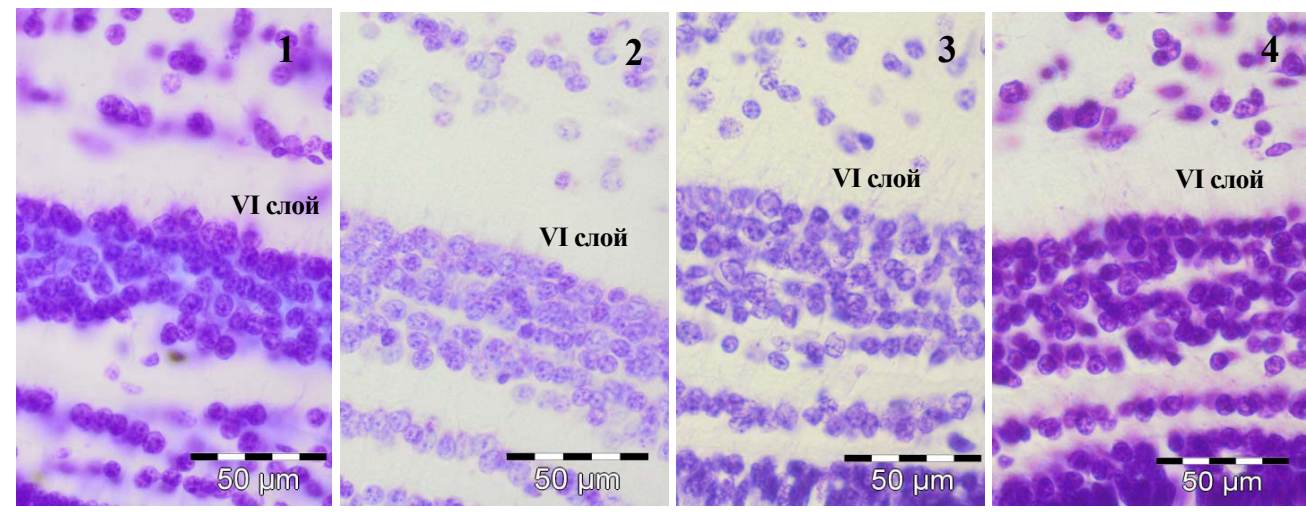

Рис. 1. Микрофотографии нейронов VI слоя крыши среднего мозга земноводных изученных видов: 1 B. bufo; 2 - R. arvalis; 3 - P. ridibundus; $4-R$. amurensis. Окраска тионином по Нисслю в модификации И.В. Викторова

Fig. 1. Microphotographs of neurons of layer VI in the midbrain roof of amphibian studied species: $1-B$. bufo; $2-R$. arvalis; $3-P$. ridibundus; $4-R$. amurensis. Staining with thionin according to Nissl modified by I.V. Viktorov
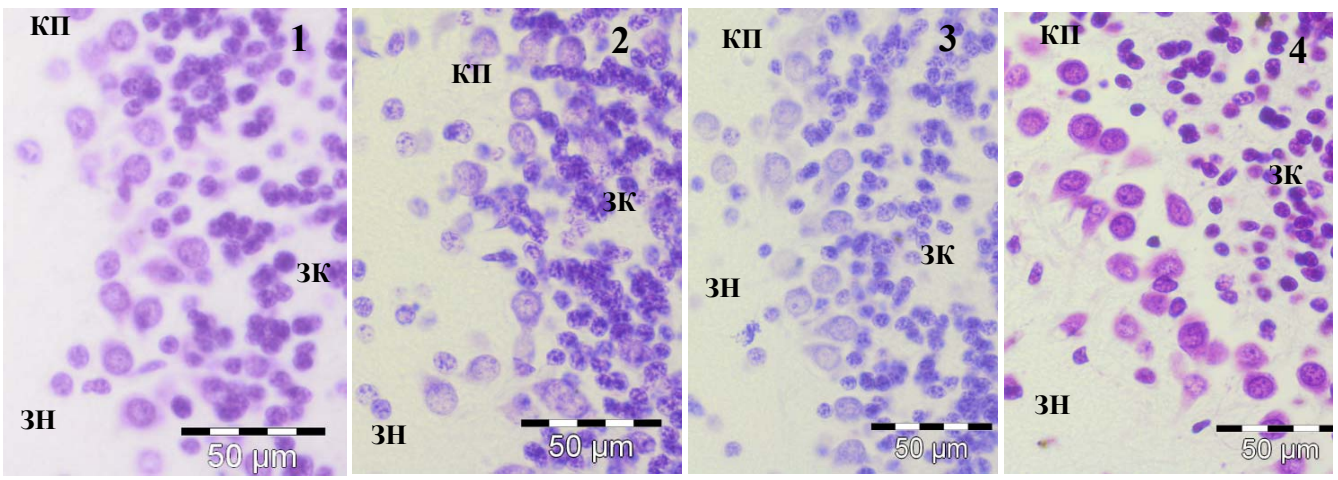

Рис. 2. Микрофотографии нейронов слоев коры мозжечка земноводных изученных видов: $1-$ B. bufo; 2 R. arvalis; 3 - P. ridibundus; 4 - R. amurensis. Окраска тионином по Нисслю в модификации И.В. Викторова. ЗН - звездчатые нейроны, КП - клетки Пуркинье, ЗК - зернистые клетки

Fig. 2. Microphotographs of neurons of cerebral cortex layers in amphibian species studied: $1-B$. bufo; $2-$ $R$. arvalis; $3-P$. ridibundus; $4-R$. amurensis. Staining with thionin according to Nissl modified by I.V. Viktorov. 3H - star-shaped neurons, KП - Purkinje cells, ЗK - grainy cells

ной организации отделов головного мозга земноводных разных таксономических групп дал М.Ф. Никитенко (1969). Головной мозг серой жабы по размерам и весу преобладает над мозгом озерной, остромордой и сибирской лягушек. У семейства Bufonidae передний отдел мозга более развит и дифференцирован, его объем составляет 51 - 63 \% от объема мозга. Представители семейства Ranidae имеют бо- лее удлиненную форму мозга и меньшее развитие переднего отдела $(14-23$ \% от объема мозга). У представителей семейства Bufonidae большее развитие получает архипаллиум, где формируются ганглиозные клетки, основывающие зачаток тонкой пластинки неопаллиума, что связано с переходом этих животных к обитанию в более засушливых участках суши. 
Эволюционно многие отделы головного мозга амфибий имеют существенную гетерогенность состава нервных клеток, как сочетающих новые, высокодифференцированные элементы, так и сохраняющих более примитивные черты, свойственные более древним группам позвоночных. Другая часть нейронов совмещает черты строения разных типов клеток и считается переходными формами. Такие механизмы эволюционных преобразований нервной системы значительно повышают эффективность функционирования нервных центров за счет сочетания признаков, свойственных различным типам нейронов, и дают возможности для выполнения более обширных функциональных задач (Андреева, Обухов, 1999).

Специальные исследования ряда авторов установили особенности анатомического строения, морфологии, физиологии, биологии и жизненного цикла у особей разных семейств, отрядов и видов земноводных (Желев, 2011; Чупров, 2013; Баранов, Городилова, 2015). У земноводных разных таксономических групп отличительные особенности выявляются на органном, тканевом, клеточном и субклеточном уровнях (Песков и др., 2009; Хандогий, Новицкий, 2012; Арзуманян и др., 2013; Plötner et al., 2010; Nishikawa et al., 2012).

Данные о сравнительной морфофункциональной характеристике клеточных популяций отделов головного мозга бесхвостых земноводных в литературе представлены крайне скудно. В работе Т.Я. Орлянской (2005) дано описание морфоцитохимических показателей нейронных популяций мозжечка остромордых лягушек. Сравнивая их с полученными нами данными, следует отметить наличие у $R$. arvalis сходных низких показателей плотности нейронов молекулярного слоя и слоя грушевидных нейронов и высокую плотность нейронов зернистого слоя коры мозжечка.
Также показатели структурного ядерноцитоплазматического коэффициента (отношение площади ядра к площади цитоплазмы клеток) во всех изученных клеточных популяциях слоев мозжечка у остромордой лягушки характеризовались однотипно высокими значениями: для эфферентных клеток Пуркинье он близок к 1, для ассоциативных нейронов молекулярного слоя и слоя грушевидных нейронов коры мозжечка получены значения выше 1. Сравнение других полученных нами данных не представляется возможным вследствие использования в проведенных исследованиях разной приборной, программной и статистической базы для снятия и обработки полученных морфометрических показателей популяций нейронов головного мозга. Также в работе (Крупкина, Орлянская, 2008) отмечена значительная вариабельность размеров и плотности нейронов среднего мозга и мозжечка у особей озерных (P. ridibundus) и остромордых лягушек (R. arvalis), что объясняется их межвидовыми различиями и особенностями экологии (среда обитания, суточная активность, питание).

При сравнении показателей морфологической организации среднего мозга и мозжечка бесхвостых земноводных с аналогичными показателями нервной системы костных рыб выявлено наличие у амфибий малодифференцированных клеток с высокими ядерноцитоплазматическими значениями, гетеротопия грушевидных нейронов в зернистый слой коры мозжечка и низкие значения их глионейронального индекса. Полученные данные объясняются филогенетическим возрастом животных и специализацией к условиям среды (Орлянская, Самсонова, 2006).

Полученные нами результаты подчеркивают морфологическую сложность мозга земноводных. Они вносят вклад в понимание организации и цитоархитектоники его отделов 
у представителей разных таксономических групп амфибий и дополняют полученные ранее фундаментальные знания в области нейроморфологии.

\section{Заключение}

В настоящее время в литературе можно найти данные об особенностях морфологических характеристик клеточных популяций ведущих отделов головного мозга для некоторых широко распространенных модельных объектов. Однако детальной информации по морфологии клеток мозга бесхвостых амфибий, которая необходима для сравнительной оценки видоспецифических различий и определения общего значения их характеристик для каждой систематической группы земноводных, недостаточно.

Данные, полученные в настоящем исследовании, дополняют имеющуюся информацию о строении ведущих отделов головного мозга (среднего мозга и мозжечка) изученных видов бесхвостых амфибий (B. bufo, R. arvalis, P. ridibundus, $R$. amurensis). Результаты, характеризующие нейрон-глиальные клеточные популяции головного мозга бесхвостых земноводных, также имеют фундаментальное значение и могут быть применены в качестве дополнительных сведений по эволюционной нейроморфологии позвоночных животных.

Отличительные видовые особенности не только связаны с размером, уровнем развития и дифференцировкой отделов голов- ного мозга земноводных, но и проявляются на популяционно-клеточном уровне его организации. Так, B. bufo имеет средние значения показателей площади тела клеток, высокие и средние значения плотности нейронов и глиоцитов. $R$. arvalis характеризуется низкими значениями показателей площади клеток, плотности нейронов и глии. У $P$. ridibundus самые высокие показатели площади клеток и умеренные значения плотности нервных и глиальных клеток. Представители $R$. amurensis отличаются средними значениями показателей площади клеток и плотности нейронов, а значения плотности глиальных клеток могут быть как высокими, так и низкими, в зависимости от слоя клеток и отдела мозга.

Полученные морфологические характеристики клеточных популяций нейронов и глии головного мозга бесхвостых земноводных позволяют сделать вывод о наличии ряда видовых специфических особенностей в организации изученных слоев крыши среднего мозга и коры мозжечка. Кроме общих адаптивных механизмов и приспособительных реакций, представители отдельных видов имеют особенные морфологические характеристики на уровне нейрон-глиальных комплексов структур головного мозга, что обусловлено длительным эволюционным развитием амфибий, филогенетическими преобразованиями их нервной системы и адаптацией к наземноводной среде обитания.

\section{Список литературы / References}

Андреева Н.Г., Обухов Д.К. (1999) Эволючионная морфология нервной системы позвоночныхх. СПб., Лань, 384 с. [Andreeva N.G., Obukhov D.K. (1999) Evolutionary morphology of the nervous system of vertebrata. Saint Petersburg, Lan', 384 p. (in Russian)]

Антонова А.М. (1969) К вопросу о классификации нейронов коры мозжечка. Архив анатомии, гистологии и эмбриологии, 5: 6-16 [Antonova A.M. (1969) On the classification of neurons in the cerebellum. Archive of anatomy, histology and embryology [Arkhiv anatomii, gistologii i embriologii], 5: 6-16 (in Russian)] 
Арзуманян М.В., Варданян А.И., Степанян И.Э., Аракелян М.С. (2013) Межпопуляционная изменчивость по размерам тела и эритроцитов у озерной лягушки, Pelophylax ridibundus (Pallas, 1771) в Армении. Современная герпетология: проблемы и пути их решения. Статьи по материалам докладов Первой междунар. молодежной конф. герпетологов России и сопредельных стран. СПб, с. 44-47 [Arzumanyan M.V., Vardanyan A.I., Stepanyan I.E., Arakelyan M.S. (2013) Inter-population variability in body size and erythrocytes in the lake frog, Pelophylax ridibundus (Pallas, 1771) in Armenia. Modern herpetology: problems and ways to solve them. Articles based on the reports of the First International Conference of Young Herpetologists of Russia and Neighboring Countries. Saint Petersburg, p. 44-47 (in Russian)]

Баранов А.А., Городилова С.Н. (2015) Земноводные лесостепи Средней Сибири. Красноярск, Изд-во КГПУ им. В.П. Астафьева, 193 с. [Baranov A.A., Gorodilova S.N. (2015) Amphibians in the forest-steppe of Middle Siberia. Krasnoyarsk, V.P. Astafyev Krasnoyarsk State Pedagogical University, 193 p. (in Russian)]

Васильев Ю.Г., Берестов Д.С. (2011) Гомеостаз и пластичность мозга. Ижевск, Изд-во Ижевской ГСХА, 216 с. [Vasil'ev Yu.G., Berestov D.S. (2011) Homeostasis and plasticity of brain. Izhevsk, Izhevsk State Agricultural Academy, 216 p. (in Russian)]

Викторов И.В. (1969) Окраска нервной ткани забуференным раствором кризилового фиолетового прочного. Современные методы морфологических исследований мозга. М., Издательство Института мозга, с. 5-7 [Viktorov I.V. (1969) Staining of nervous tissue with buffered solution of crisologo purple durable. Modern methods of morphological brain research. Moscow, Brain Research Institute, p. 5-7 (in Russian)]

Гланц С. (1999) Медико-биологическая статистика. М., Практика, 459 с. [Glants S. (1999) Medical and biological statistics. Moscow, Praktika, 459 p. (in Russian)]

Дробленков А.В., Наумов Н.В., Монид М.В., Сосин В.В., Пеньков Д.С., Прошин С.Н., Шабанов П.Д. (2013) Реакция клеточных элементов головного мозга крыс на циркуляторную гипоксию. Медицинский академический журнал, 13(4): 19-28 [Droblenkov A.V., Naumov N.V., Monid M.V., Sosin D.V., Penkov D.S., Proshin S.N., Shabanov P.D. (2013) Reactive changes of the rat brain cell elements due to circulatory hypoxia. Medical Academic Journal [Medicinskij akademicheskij zhurnal], 13(4): 19-28 (in Russian)]

Дунаев Е.А., Орлова В.Ф. (2012) Земноводные и пресмыкающиеся России. Москва, Фитон+, 320 c. [Dunaev E.A., Orlova V.F. (2012) Amphibians and reptiles of Russia. Moscow, Fiton+, 320 p. (in Russian)]

Желев Ж.М. (2011) Биоиндикационная оценка состояния двух биотопов в южной Болгарии на основании флюктуирующей асимметрии и фенетического состава популяций озерной лягушки Rana ridibunda Pallas, 1771 (Anura, Amphibia, Ranidae) и краснобрюхой жерлянки Bombina bombina Linnaeus, 1761 (Amphibia, Anura, Discoglossidae) в условиях синтопического обитания. Перспективы науки, 7: 7-18 [Zhelev Zh.M. (2011) Bio-indicative evaluation of the status of two biotopes in southern Bulgaria on the basis of the indicators of fluctuating asymmetry and phenetic composition of populations of the marsh frog Rana ridibunda Rallas, 1771 (Anura, Amphibia, Ranidae) and european fire-bellied toad Bombina bombina Linnaeus, 1761 (Amphibia, Anura, Discoglossidae) in the conditions of syntopic habitats. Science Prospects [Perspektivy nauki], 7: 7-18 (in Russian)] 
Жуков Е.Л., Медведева Н.Н. (2015) Реакция внутренних органов кроликов на внутривенное введение наноалмазов. Современные проблемы науки и образования, 6 [Zhukov E.L., Medvedeva N.N. (2015) Reaction of same internal organs of rabbits by intravenous injection of nanodiamonds. Modern Problems of Science and Education [Sovremennye problemy nauki i obrazovaniya], 6 (in Russian)]

Каниева Н.А. (2005) Морфофункциональное состояние головного мозга карпа под влиянием нефти. Вестник Оренбургского государственного университета, 6: 132-134 [Kanieva N.A. (2005) Morphofunctional state of the carp's brain under the influence of oil. Vestnik of the Orenburg State University [Vestnik Orenburgskogo gosudarstvennogo universiteta], 6: 132-134 (in Russian)]

Карамян А.И. (1970) Функииональная эволючия мозга позвоночных. Л., Наука, 304 с. [Karamyan A.I. (1970) Functional evolution of the brain of vertebrates. Leningrad, Nauka, 304 p. (in Russian)]

Крупкина В.С., Орлянская Т.Я. (2008) Сравнительная характеристика нейронных популяций мозжечка и Tectum opticum среднего мозга некоторых видов наземных амфибий. Морфология, 3: 60 [Krupkina V.S., Orlyanskaya T.Y. (2008) Comparative characterization of neuron populations of the cerebellum and Tectum opticum in the midbrain of some species of terrestrial amphibians. Morphology [Morfologiya], 3: 60 (in Russian)]

Лешко А.А. (1968) Материалы по морфологии мозжечка некоторых млекопитающих. 3-я Зоологическая конференщия АН БССР. Отдел зоологии и паразитологии. Тезисы докладов. Минск, с. 339-340 [Leshko A.A. (1968) Data on the morphology of the cerebellum of some mammals. The $3^{\text {rd }}$ Zoological Conference of Academy of Sciences of the Byelorussian SSR. Department of Zoology and Parasitology. Abstracts. Minsk, p. 339-340 (in Russian)]

Никитенко М.Ф. (1969) Эволюиия и мозг. Минск, Наука и техника, 344 с. [Nikitenko M.F. (1969) Evolution and brain. Minsk, Nauka i tekhnika, 344 p. (in Russian)]

Обухов Д.К., Пущина Е.В. (2013) Нейрогенез и пролиферативные зоны в ЦНС взрослых позвоночных животных. Усnехи современного естествознания, 5: 18-22 [Obukhov D.K., Pushchina E.V. (2013) Neurogenesis and proliferation zones in the CNS of adult vertebrates. Advances in Contemporary Natural Sciences [Uspekhi sovremennogo estestvoznaniya], 5: 18-22 (in Russian)]

Обухов Д.К., Пущина Е.В., Вараксин А.А. (2015) Структура пролиферативных зон в центральной нервной системе ЦНС взрослых позвоночных животных. Вопросы морфологии ХХІ века. Вып. 4. Учение о тканях. Гистогенез и регенерация. Сборник научных трудов. СПб., ДЕАН, с. 43-51 [Obukhov D.K., Pushchina E.V., Varaksin A.A. (2015) The structure of the proliferative zones in the CNS of adult vertebrates. Aspects of morphology of the XXI century. Vol. 4. Collection of scientific works "The doctrine of the tissues. Histogenesis and regeneration". Saint Petersburg, DEAN, p. 43-51 (in Russian)]

Орлянская Т.Я. (2004) Пластичность нейронных популяций ганглиозного слоя мозжечка в эволюционно-прогрессивном ряду позвоночных животных. Омский научный вестник, 1: 217-219 [Orlyanskaya T.Ya. (2004) Plasticity of neuron populations of the ganglion layer of the cerebellum in the evolutionary-progressive series of vertebrates. Omsk Scientific Bulletin [Omskiy nauchnyi vestnik], 1: 217-219 (in Russian)]

Орлянская Т.Я. (2005) Закономерности проявления морфоцитохимических показателей на уровне популяций функционально различных нейронов мозжечка в филогенезе позво- 
ночных животных. Структурно-функциональные и нейрохимические закономерности асимметрии и пластичности мозга. Материалы конференции НИИ мозга. М., Икар, с. 211-214 [Orlyanskaya T.Ya. (2005) Regularities of manifestation of morphocytochemical parameters at the level of populations of functionally distinct neurons of the cerebellum in the phylogeny of vertebrates. The structural/functional and neurochemical patterns of brain asymmetry and plasticity. Proceedings of Conference of Brain Research Institute. Moscow, Icar, p. 211-214 (in Russian)]

Орлянская Т.Я., Самсонова А.В. (2006) Анализ нейронных популяций tectum opticum среднего мозга и мозжечка низших позвоночных. Морфология, 4: 96 [Orlyanskaya T.Ya., Samsonova A.V. (2006) Analysis of neuron populations of tectum opticum in the midbrain and cerebellum of the lower vertebrata. Morphology [Morfologiya], 4: 96 (in Russian)]

Орлянская Т.Я., Ильченко А.В., Трубина Н.И., Христова Ю.Ю. (2006) Пластичность нейронных популяций переднего мозга у молодых животных при экзогенном воздействии. Омский научный вестник, 3(37(1)): 80-83 [Orlyanskaya T.Ya., Il'chenko A.V., Trubina N.I., Khristova Yu.Yu. (2006) Plasticity of neuron populations of the forebrain in young animals under exogenous impact. Omsk Scientific Bulletin [Omskiy nauchnyi vestnik], 3(37(1)): 80-83 (in Russian)]

Орлянская Т.Я., Крупкина В.С., Чижова С.В., Устинова Т.И. (2008) Гетерогенность нейронных популяций мозжечка в филогенезе позвоночных. Вопросы морфологии ХХІ века. Bыn. 1. Сборник научных трудов, посвященных 100-летию кафедры медицинской биологии СПбГМА им. И.И. Мечникова. СПб., ДЕАН, с. 223-228 [Orlyanskaya T.Ya., Krupkina V.S., Chizhova S.V., Ustinova T.I. (2008) The heterogeneity of the neuron populations of the cerebellum in the phylogeny of vertebrates. Aspects of morphology of the XXI century. Vol. 1. Collection of scientific works dedicated to the 100th anniversary of Medical Biology Department at I. I. Mechnikov St. Petersburg State Medical Academy. Saint Petersburg, DEAN, p. 223-228 (in Russian)]

Песков В.Н., Петренко Н.А., Реминный В.Ю. (2009) Межвидовые различия и половой диморфизм по пропорциям тела у европейских зеленых лягушек (Amphibia, Anura, Ranidae) фауны Украины. Зоологічна наука у сучасному суспільстві. Матеріали Всеукраїнської науч. конф. Киев, Фітосоціоцентр, с. 369-374 [Peskov V.N., Petrenko N.A., Remennyi V.Yu. (2009) Interspecific differences and sexual dimorphism in body proportions among European green frogs (Amphibia, Anura, Ranidae) of Ukraine fauna. Zoological science in modern society. Proceedings of Ukrainian Scientific Conference. Kiev, Fitosotsiotsentr, p. 369-374 (in Russian)]

Пущина Е.В., Жарикова Е.И., Вараксин А.А. (2016) Нейрогенез у взрослых позвоночных животных: вопросы адаптации, эволюции и функциональной специализации. Тихоокеанский медицинский журнал, 2: 55-61 [Puschina E.V., Zharikova E.I., Varaksin A.A. (2016) Neurogenesis in the adult vertebrate animals: the issues of adaptation, evolution and functional specialization. Pacific Medical Journal [Tihookeanskij medicinskij zhurnal], 2: 55-61 (in Russian)]

Самосудова Н.В., Реутов В.П., Ларионова Н.П. (2011) Слияние клеток-зерен мозжечка лягушки при токсическом воздействии глутамата и NO-генерирующего соединения. Морфология, 140(4): 13-17 [Samosudova N.V., Reutov V.P., Larionova N.P. (2011) Fusion of frog cerebellar granule cells induced by toxic effects of glutamate and no-generating compound. Morphology [Morfologiya], 4: 13-17 (in Russian)]

Самосудова Н.В., Реутов В.П., Ларионова Н.П., Чайлахян Л.М. (2007) Нейроно-глиальные контакты, образующиеся в мозжечке при электрической стимуляции в присутствии NO-

$$
-457-
$$


генерирующего соединения. Морфология, 131(2): 53-58 [Samosudova N.V., Reutov V.P., Larionova N.P., Chailakhian L.M. (2007) Neuron-glial junction formation in cerebellum after electrical stimulation in presence of NO-generating substance. Morphology [Morfologiya], 131(2): $53-58$ (in Russian)]

Сепп Е.К. (1949) История развития нервной системы позвоночных. М., Медгиз, 422 с. [Sepp E.K. (1949) The history of the development of the nervous system of vertebrates. M., Medgiz, 422 p. (in Russian)]

Устинова Т.И., Медведева Н.Н., Салмина А.Б., Малиновская Н.А. (2015) Морфологическая характеристика нейро-глиальных популяций спинного мозга крыс после воздействия табачным дымом. Сибирское медицинское обозрение, 3: 38-41 [Ustinova T.I., Medvedeva N.N., Salmina A.B., Malinowskaya N.A. (2015) Morphological characteristics of neuro-glial populations of rat spinal cord following tobacco smoke exposure. Siberian Medical Review [Sibirskoe medicinskoe obozrenie], 3: 38-41 (in Russian)]

Фанарджян В.В. (1995) Морфофункциональные основы взаимодействия переднего мозга и мозжечка. Успехи физиологических наук, 2: 317 [Fanardjian V.V. (1995) Morphological and functional basis of the forebrain and cerebellum interaction. The Advances in Physiological Sciences [Uspekhi fiziologicheskikh nauk], 2: 317 (in Russian)]

Фанарджян В.В.(2000)Мозжечокиорганизацияповедения.Сравнительно-физиологический аспект. Журнал эволюиионной биохимии и физиологии, 3: 178-183 [Fanardjian V.V. (2000) The cerebellum and organization of behavior. Comparative-physiological aspect. Journal of Evolutionary Biochemistry and Physiology [Zhurnal evolyutsionnoy biokhimii i fiziologii], 3: 178-183 (in Russian)]

Хандогий А.В., Новицкий Р.В. (2012) Пространственная изменчивость и проявление полового диморфизма Bufonidae (Amphibia) на территории Минской области. Весиі БДПУ, 3: 23-29 [Khandogiy A.V., Novitskyi R.V. (2012) Spatial variability and the manifestation of sexual dimorphism in Bufonidae (Amphibia) in the territory of the Minsk Oblast. Bulletin of Belarusian State Pedagogical University [Vesci BDPU], 3: 23-29 (in Russian)]

Чупров С.М. (2013) Атлас земноводных и пресмыкающихся Красноярского края. Красноярск, Издательствово СФУ, 52 с. [Chuprov S.M. (2013) Atlas of amphibians and reptiles of Krasnoyarsk Krai. Krasnoyarsk, Siberian Federal University, 52 p. (in Russian)]

Butler A.B., Hodos W. (2005) Comparative vertebrate neuroanatomy: evolution and adaptation. San Diego, John Wiley \& Sons, 744 p.

Chetverukhin V.K., Polenov A.L. (1993) Ultrastructural radioautographic analysis of neurogenesis in the hypothalamus of the adult frog, Rana temporaria, with special reference to physiological regeneration of the preoptic nucleus. I. Ventricular zone cell proliferation. Cell Tissue Research, 271(2): $341-350$

Comparative neurology of the optic tectum (1984) Vanegas H. (ed.) New York, Plenum Press, $850 \mathrm{p}$.

Font E., Desfilis E., Perez-Canellas M.M., Garcia-Verdugo J.M. (2001) Neurogenesis and neuronal regeneration in the adult reptilian brain. Brain Behavior and Evolution, 58(5): 276-295

Frost D.R., Grant T., Faivovich J., Bain R.H., Haas A., Haddad C.F.B., De Sa R.O., Channing A., Wilkinson M., Donnellan S.C., Raxworthy C.J., Campbell J.A., Blotto B.L., Moler P., Drewes R.C., Nussbaum R.A., Lynch J.D., Green D.M., Wheeler W.C. (2006) The amphibian tree of life. Bulletin of the American Museum of Natural History, 297: 1-370

$$
-458-
$$


Nishikawa K., Matsui M., Yong H.S., Ahmad N., Yambun P., Belabut D.M., Sudin A., Hamidy A., Orlov N.L., Ota H., Yoshikawa N., Tominaga A., Shimada T. (2012) Molecular phylogeny and biogeography of caecilians from Southeast Asia (Amphibia, Gymnophiona, Ichthyophiidae), with special reference to high cryptic species diversity in Sundaland. Molecular Phylogenetics and Evolution, 63(3): 714-723

Plotner J., Uzzell T., Beerli P., Akin C., Bilgin C.C., Haefeli C., Ohst T., Kohler F., Schreiber R., Guex G.D., Litvinchuk S.N., Westaway R., Reyer H.U., Pruvost N., Hotz H. (2010) Genetic divergence and evolution of reproductive isolation in eastern mediterranean water frogs. Evolution in Action. Glaubrecht M. (ed.) Springer, Berlin, Heidelberg, p. 373-403

Pyron R.A., Wiens J.J. (2011) A large-scale phylogeny of Amphibia including over 2800 species, and a revised classification of extant frogs, salamanders, and caecilians. Molecular Phylogenetics and Evolution, 61(2): 543-583

Striedter G.F. (2005) Principles of brain evolution. Sinauer Associates, USA, 436 p.

Ulinski P.S. (1990) Nodal events in forebrain evolution. Netherlands Journal of Zoology, 40(1-2): $215-240$ 